\title{
norden
}

\section{Conference on Competitive and Sustainable Aquaculture}

Dimensions and Tools of Competitive and Sustainable Aquaculture in Northern Europe

TemaNord Conference Proceedings 





\section{Conference on Competitive and Sustainable Aquaculture}

Dimensions and Tools of Competitive and Sustainable Aquaculture in Northern Europe

Editors Sirkka Heinimaa and Riitta Rahkonen 


\section{Conference on Competitive and Sustainable Aquaculture}

Dimensions and Tools of Competitive and Sustainable Aquaculture in Northern Europe

TemaNord 2012:518

http://dx.doi.org/10.6027/TN2012-518

ISBN 978-92-893-2345-1

(c) Nordic Council of Ministers 2012

This publication has been published with financial support by the Nordic Council of Ministers. However, the contents of this publication do not necessarily reflect the views, policies or recommendations of the Nordic Council of Ministers.

www.norden.org/en/publications

\section{Nordic co-operation}

Nordic cooperation is one of the world's most extensive forms of regional collaboration, involving Denmark, Finland, Iceland, Norway, Sweden, and the Faroe Islands, Greenland, and Åland.

Nordic cooperation has firm traditions in politics, the economy, and culture. It plays an important role in European and international collaboration, and aims at creating a strong Nordic community in a strong Europe.

Nordic cooperation seeks to safeguard Nordic and regional interests and principles in the global community. Common Nordic values help the region solidify its position as one of the world's most innovative and competitive.

\section{Nordic Council of Ministers}

Ved Stranden 18

DK-1061 Copenhagen K

Phone (+45) 33960200

www.norden.org 


\section{Content}

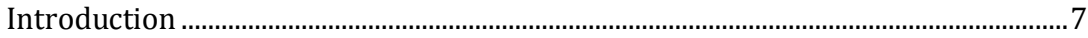

Keynote: Aquaculture on the global scale and the state of aquaculture in the Nordic countries 9

Summary of the discussion................................................................................ 11

1. Sustainability - Success in competing for coastal and freshwater resources and recycling of nutrients.................................................................... 13

1.1 General summary of the presentations and discussions........................ 13

1.2 Summaries of the presentations................................................................. 14

2. Profitability - Success in competing in global product markets and innovations

2.1 General summary of the presentations and discussions........................ 21

2.2 Summaries of the presentations............................................................... 22

3. Acceptability - Success in competition for the souls of customers -

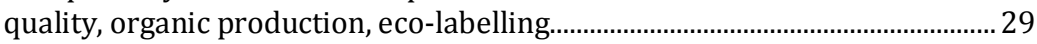

3.1 General summary of the presentations and discussions......................... 29

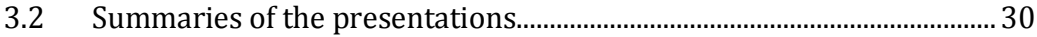

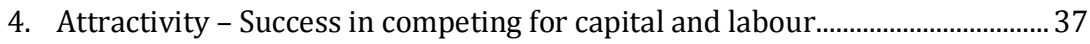

4.1 General summary of the presentations and discussions..........................37

4.2 Summaries of the presentations.................................................................. 38

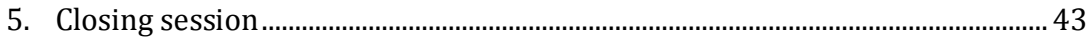

5.1 Helsinki Declaration on Competitive and Sustainable Aquaculture in the Baltic Region.................................................................. 43

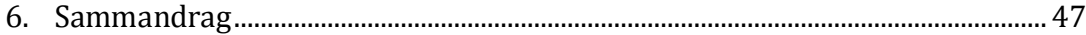

6.1 Hållbar utveckling inom akvakultur ............................................................. 47

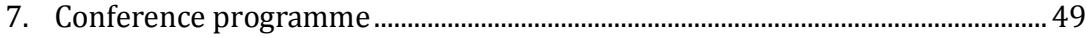





\section{Introduction}

The Conference on Competitive and Sustainable Aquaculture was held on 4-5 October 2011 in the House of the Estates in Helsinki, Finland. The goal of the conference was to provide a forum for the authorities, the aquaculture industry, researchers and other stakeholders to discuss opportunities and challenges for aquaculture in Northern Europe. Moreover, the conference aimed at implementing the EU strategy for the Baltic Sea Region and its flagship project on aquaculture. The conference was part of the Finnish Presidency of the Nordic Council of Ministers (NCM) in 2011. The conference was also financed by the NCM.

Globally, aquaculture has been the fastest growing food production sector over the past two decades. In contrast to the world trend, production in the EU - and especially the Baltic Sea region - has stagnated or even declined slightly during the 2000s. On the other hand, a rapid increase in aquaculture production has been seen in Norway. The great potential of aquaculture for feeding a growing human population in an era of declining wild stocks (the "Blue Revolution") is widely acknowledged, but new production must be built on sustainable practices and technologies.

The conference was organised by the Finnish Game and Fisheries Research Institute and the Ministry of Agriculture and Forestry. A separate Workshop on Recirculating Aquaculture Systems, also financed by the NCM and organised by Technical University of Denmark (DTU), was linked to the conference (www.NordicRAS.net). Together, these two consecutive events formed the Aquaculture Forum.

The conference brought together 125 participants from thirteen different European countries. There was broad representation from the aquaculture sector in Europe: central and local administrations, research institutes, universities, industry and a range of other organisations.

Altogether seventeen presentations were held in four themes: Sustainability, Profitability, Acceptability and Attractivity. 
Each theme was formed of three to four presentations. After each session, the speakers formed a panel and the discussion was led by moderator Courtney Hough from the Federation of European Aquaculture Producers. At the end the conference, the participants agreed on the Helsinki Declaration on Competitive and Sustainable Aquaculture in the Baltic Region.

The presentations, the Declaration and the Conference report can be downloaded from the Conference home page http://www.rktl.fi/english/ economics_and_soci-ety/aquaculture_forum/.

The report was compiled by PhD Sirkka Heinimaa from VesiSirkka Ltd. 


\section{Keynote: Aquaculture on the global scale and the state of aquaculture in the Nordic countries}

Brian Thomsen, Director, Danish Aquaculture Organization, Denmark

In the opening keynote, Brian Thomsen briefly summarised the global state of aquaculture. Consumption of fish food per capita has increased in recent years, while supply from fisheries has decreased. Currently, aquaculture accounts for almost half of the global fish food supply and is the fastest growing food producing sector in the world. Annual aquaculture production is 53 million tonnes and was worth USD 98 billion in 2008. About 87 per cent of this production is carried out in Asia, and China alone produced nearly 33 million tonnes of aquatic food. The growth in aquaculture production on the other continents is still quite moderate. However, there is an increasing need for aquatic food production. Given the projected population growth, an additional 40 million tonnes is needed by 2030 to maintain the current per capita consumption.

Brian Thomsen compared to the state of aquaculture in Europe to a Ferrari in a garage: we have the technology and know-how but still the car is not moving. On the contrary, aquatic food production has decreased in the EU27 countries in recent years, standing at 1.35 million tonnes in 2008. The only European country that has significantly been able to increase fish farming is Norway, and is the seventh biggest producer in the world with one million tonnes of production in 2010. Even when all aquaculture production in Europe is totalled, it is still small compared to im- 
ports, which amounted to around 11 million tonnes in 2009. The value of this deficit was about USD 10 billion in 2008.

Brian Thomsen summarised the reasons why aquaculture is limping in the EU. It is clear that the goals of the aquaculture strategies adopted earlier have not been reached. The main reasons for the current situation in the EU are the extensive legal armoury on aquaculture, increasingly stringent regulations on aquaculture, dwindling access to water resources and land suitable for aquaculture and the negative environmental image. The tight regulation framework puts European aquaculture in a paradoxical situation, where research and development know-how is exported and aquatic food is imported.

Brian Thomsen was, however, optimistic about the future of aquaculture in the EU. We have the resources, the know-how and the vision to increase production. There is strong market demand for high quality, healthy aquatic food that can be produced ecologically and efficiently, and which has lower environmental impacts than other forms of livestock production. Hopefully, the ongoing reform of the EU Common Fisheries Policy will give a better framework for operation.

Finally, Brian Thomsen gave an example from Denmark on how aquaculture can increase with hard work. What is needed first is a strategy and a vision of growth that is reachable, and then the technology, skills, capital and a framework that will enable the growth. Definitions of the benefits of the development, such as new jobs, income, etc. and growth killers, such as the regulation of feed amount, nitrogen and water licences, are also needed. To create a suitable framework, all stakeholders have to negotiate the regulation and implementation. In 2010, Denmark developed a new, coherent, efficient and flexible aquaculture regulation for freshwater farms which addresses externalities. The aim is to move from input regulation (amount of feed) towards output based regulation (discharge quotas), which enable farmers to increase production within the allowable quotas. The aim is further to make it possible for farms to buy nitrogen discharge quotas from other farms.

The presentation can be downloaded from: http://www.rktl.fi/www/uploads/pdf/Aquaculture\%20Forum/opening_and_intoduction_brian_th omsen.pdf. 


\section{Summary of the discussion}

In response to the question as to how Thomsen sees the EU Common Fishery Policy, he answered that it is good that the EU has a strategy, but the missing link is executing the strategy. The obstacles in the way of aquaculture growth are numerous. The key issues are clear goal and regulation framework. It is also important that the strategy is taken into practice. The period of licensing for fish farms should be long enough, at least ten years, and the environmental regulation should also aim at maintaining or even improving the sectors competitiveness. The divergence in firms' size in the aquaculture industry is high, from family firms to large companies, and this should also be taken into account.

The paradoxical situation that fish as a food has a good image but aquaculture has a bad image raised discussion. Today's aquaculture technology is very environmentally friendly, but this issue has not been highlighted enough. The aquaculture sector needs to collect data on this issue and communicate it to relevant stakeholders.

Courtney Hough, in his role as moderator, reminded the conference that consumers' first priority when buying fish products is price. This should be borne in mind when regulatory frameworks and other instruments are developed. 



\section{Sustainability - Success in competing for coastal and freshwater resources and recycling of nutrients}

\subsection{General summary of the presentations and discussions}

In this session, the sustainability of aquaculture was considered mainly from space and feed perspectives. The basis of sustainable aquaculture is the location of suitable places for farming activities. It affects fish welfare and the efficiency of operations and everything in between. It can also diminish the side effects of farming like prevent eutrophication of area. Farmers have to compete with other users for water areas and conflicts between them are a common problem in Nordic countries. Local officials can also have lack of knowledge on aquaculture operations. This causes difficulties for farmers in terms of acquiring new licences. Spatial planning of coastal areas has led to positive results in solving area conflicts in Norway. Environmental stakeholders also share the opinion that this tool is useful. This knowledge has now spread also to fresh waters as part of the AQUABEST project in the Baltic Sea region.

In freshwater farming, hydropower basins were brought up as potential venues for fish farms. Hydropower basins are usually oligotrophic and their ecological status has decreased from their natural state. In the basin, the increase of phosphorus and nitrogen levels can even improve production and fish populations.

The nutrient load of fish farms is usually one of the main problems. In order to acquire a permit for bigger nutrient loads, different kinds of compensation for nutrient removal have been proposed, such as fishing lower 
value fish or using it as raw material for fish feed in the Baltic Sea region. Implementation of the Baltic feed use, its nutrient levels, manufacturing, price and its binding nature all raised discussion. The AQUABEST project will provide more understanding for these issues.

In the future, it may be possible to manufacture feed from the nutrients of waste waters, such as sugars from pulp rinse water, by using microbiological fermentation. This, together with population management fishing and its use in feeds, and mussels farming, means that aquaculture can become an environmental service, leading to a decrease in nitrogen levels in the Baltic Sea region in the future.

\subsection{Summaries of the presentations}

\subsubsection{Bottlenecks in the Baltic Sea region aquaculture and their potential solutions}

Jouni Vielma, Senior Researcher, Finnish Game and Fisheries Research Institute, Finland

At the outset, Jouni Vielma stressed the importance of aquaculture as a food producer on a global scale. Whereas global aquaculture production increased by 8.0 per cent in 2000-2009, in Europe the increase was only +2.3 per cent. However, in the EU27 countries, production has decreased by 1.0 per cent, and this decrease has been strongest in the Baltic Sea region ( -2.0 per cent).

European Union has identified this challenge and adopted aquaculture as a flagship project BESTAQ in the EU's strategy for the Baltic Sea Region (BSR). The common sea area and resources creates interdependence between countries, despite their heterogeneity. The main idea behind the first macro-regional strategy within the EU is to create a model of regional cooperation for new ideas, approaches and practices. The key challenges for BSR strategy are to make the area 1) environmentally sustainable; 2) prosperous; 3) accessible and attractive; and 4) safe and secure. One of the fifteen priorities of BSR strategy is to reinforce the sustainability of 
aquaculture, forestry and fisheries. The task for BESTAQ in this priority area is to encourage the industry to use sustainable aquaculture methods.

BESTAQ-project conducted a questionnaire among BSR stakeholders of aquaculture. Question themes were 1) aquaculture as a global food producer; 2) aquaculture development in the BSR; 3) traditional nutrient load management tools, and 4) new environmental management tools. Spatial planning of fish farms, the use of Baltic fish for feed in fish farming and nutrient removal from water by fishing are, among other things, the new environmental tools.

The aquaculture and fishing industries, fisheries administration, research and education saw that the compensation for nutrient removal, use of Baltic Sea sourced feed, bigger licences for Baltic feed use and bigger licences for favourable areas are useful management tools. Environmental stakeholders did not regard these tools as very useful, but they agreed on the usefulness of better spatial planning with others.

BESTAQ team prepared an application for the Baltic Sea Region Programme 2007-2013, which decided to finance the project AQUABEST. Fourteen partners from eight countries will promote the region aquaculture through the following four development themes: 1) Making the licensing system more coherent, to encourage the adaption of eco-efficient technologies and practices; 2) Spreading spatial planning knowledge throughout the area; 3) Decreasing nutrients importation from the oceans by using regional feed ingredients, and 4) Assessing the feasibility of recirculation farming and transferring technology throughout the area.

The presentation can be downloaded from: http://www.rktl.fi/www/uploads/pdf/Aquaculture\%20Forum/theme_1_1_sustainability_vielma.pdf. 


\subsubsection{Marine spatial planning and aquaculture - a Norwegian perspective}

Martin Bryde, Deputy Director General, Department of Aquaculture, Seafood and Markets, Norwegian Ministry of Fisheries and Coastal Affairs, Norway

Martin Bryde discussed the positive effects of spatial planning in Norway. There, aquaculture production has been increasing for years while the number of farms has decreased, which has led to bigger production units. Conflicts with other users are difficult to avoid because sea areas are utilised to a high degree for other use, for example for fishing and spawning grounds, shipping lanes and marine protected areas.

Spatial planning and site structure are important tools for the longterm environmentally sustainable development of the aquaculture industry. It takes the carrying capacity of the area, other users and fish welfare into account, prevents pollution and the spreading of diseases, and protects important genetic resources of wild stocks. It also improves the industry's reputation and public interest in it.

In 2009, a commission was set up to propose new general principles for aquaculture site structure. Their main proposal is to divide the coast into production areas based on the risk of spreading disease. The production areas could then be divided into sea transfer and fallowing areas. Principles for a future site structure will be discussed further in a forthcoming green paper on Norwegian fisheries and aquaculture policy. In the same year the Planning and Building Act, which also covers the coastal sea areas, was completely revised and updated. It provides provisions for differentiating between main and sub-objectives. Now it is possible to designate exclusive areas to specific aquaculture species in the plans. The Act has become an important tool for resolving area conflicts in the coastal zone before concrete applications for aquaculture sites are submitted. Currently more than 90 per cent of Norwegian coastal municipalities have spatial plans covering sea areas.

The presentation can be downloaded from: http://www.rktl.fi/www/uploads/pdf/Aquaculture\%20Forum/theme_1_3_sustainability_bryde.pdf. 


\subsubsection{Potential and limitations of aquaculture in freshwater systems}

Jens Andersson, Coordinator, Regional Council of Jämtland, Sweden

Jens Andersson summarised the challenges of aquaculture in a freshwater system. Freshwater aquaculture is still relatively small scale in the Nordic countries, with Denmark being the biggest producer at 25,000 tonnes per year and Norway the smallest at 500 tonnes.

A characteristic of freshwater is that it is fundamental to human life. Freshwater systems are closed and hence the risk of eutrophication and genetic interchange between farmed and wild populations are higher compared to marine systems. Freshwater systems are covered by ice during winter in many regions of Northern Europe, which can inflict high levels of physical stress on equipment. A large proportion of freshwater systems are located in relatively remote areas where infrastructure in the vicinity of many suitable locations for farming is relatively poorly developed.

Jens Andersson also summarised the potential for freshwater aquaculture. Hydropower basins have already been affected in such a way that aquaculture should not decrease their ecological status, but rather increase their production. The development of recirculation systems and submerged farming methods are a prioritised issue in the aquaculture industry. Rural development is on the agenda in many regions and aquaculture may very well be a driver for such a development.

In the AQUABEST project, Jämtland in Sweden is used as the reference location for testing spatial planning in inland waters to find new places for fish farms.

The presentation can be downloaded from: http://www.rktl.fi/www/uploads/pdf/Aquaculture\%20Forum/theme_1_4_sustainability_anderss on.pdf. 


\subsubsection{Closing the nutrient loop: one key factor in achieving sustainable fish farming}

Anders Kiessling, Professor, Swedish University of Agricultural Sciences, Sweden

Anders Kiessling presented a future perspective on how nutrients can be circulated to fish feed. Currently, nutrient circulation in fish farms is open where nutrients are external resources and after use they accumulate locally. In the future the goal is to re-circulate nutrients.

It is also possible to use waste nutrients from other industries as material for fish feed using microbiological fermentation. For example, from short sugars of the pulp rinse water microbes can form proteins used in fish feed. In principle, from rinse water of one pulp factory can be produced 32,500 tonnes of fish feed which can grow 29,500 tonnes of rainbow trout or char annually. All the Swedish mills could produce a total of 1,200,000 tonnes of fish feed, with an estimated value of about EUR 1.5 billion per year. This amount is enough to cover the annual Norwegian need for feed used in salmon farming.

From nutrient content the waste can be divided as raw material for new products. Waste with a high nitrogen and phosphorus content can be used as raw material for fish and poultry feed, and intermediate content waste can be used for pig feed and soil fertilizer. Waste with a high content of carbon and hydrogen is more suitable for energy production. The reasons why micro-scale biomass and bio-proteins can be used as raw material in fish feed are because they are analogous in amino acid composition.

Potential places for fish farms are hydropower basins because there are ultraoligotrophic. An estimated 100,000 tonnes of farming would increase the phosphorus and nitrogen levels of water only to the pre-dam level. An increase of nutrients in water positively affects fish populations in a basin, thus increasing fishing possibilities. For example, in Landösjön in Sweden fish farming has increased the levels of fishing tourism in the area.

In the future, aquaculture could be seen as an environmental service which can decrease nitrogen content in the Baltic Sea. Nitrogen can be removed from the Baltic Sea by population management fishing and mussel farming. To decrease nitrogen import to the Baltic Sea, fish can be used 
in feed and organic waste waters as raw material in micro meals. Theoretically is it possible that $1 \mathrm{~kg}$ of farmed fish can remove $77 \mathrm{~g}$ of nitrogen, which would result in a $32 \mathrm{~g}$ net gain in fish and a $45 \mathrm{~g}$ loss which can be used to enrich oligotrophic basins.

The presentation can be downloaded from: http://www.rktl.fi/www/uploads/pdf/Aquaculture\%20Forum/theme_1_4_sustainability_anderss on.pdf. 



\section{Profitability - Success in competing in global product markets and innovations}

\subsection{General summary of the presentations and discussions}

This session considered what effects profitability of fish farming and why Norwegian salmon has been successful in the global seafood market. The profitability of fish farming affects the price of feed and oil, the selling price and the health of fish. Efficient and effective production is no longer enough to ensure a competitive advantage. Today it is important to take control of the whole value chain, and to understand markets and marketing. The licence policy should support fish farming so that long-term partnerships with operators of processors and trade can be concluded.

Behind the success of Norwegian salmon industry are favourable circumstances allowing for effective production, cooperation between stakeholders, investment in marketing and innovations to improve the efficiency of sale. The Norwegian salmon industry has been able to response to increased consumer demand for processed products. In the seafood value chain the push of supply of available fish from producers is turned to the pull of demand for the right kind of fish products from supermarkets. Product launches of salmon have increased but not as much as chicken in recent years.

Not only has the variety of processed fish products increased, but also the number of new farmed species. Research \& development and time are required to make the production of a new species profitable. Sometimes success can depend on a small thing in farming practice, such as when fish are vaccinated. 
In terms of the price of mass fish species, Europe may not able to compete but it can compete in terms of quality, environmentally sound approaches and producing different fish species. Organic farming has its own small share in the market. New rearing technologies like indoor warm water and recirculation farming could give inland farming new possibilities to compete in aquaculture markets.

In response to the question: would you recommended aquaculture to your children, the answers were yes and no. There are easier ways of earning a living than through fish farming, as it usually demands lot of effort. Starting from zero is usually difficult. It can be difficult to find staff so you should be aware of the level of attractiveness of the business.

\subsection{Summaries of the presentations}

\subsubsection{Innovation and adding value in the production chain for fish products}

Renate Enemark Bergersen, Senior Consultant, Econ Pöyry Norway and Audun Iversen, Scientist, Nofima, Norway

This presentation described which innovations lies behind the success of Norwegian salmon industry and what it will take to continue this success in the future. In the last twenty years, exports of Norwegian salmon have increased from 100,000 tonnes to around 1 million tonnes. During this time technology and productivity innovations have been introduced and work has been carried out to improve the efficiency of sale. Small-scale labour intensive farming has moved towards large-scale efficient automatic farming. The breeding of salmon and more efficient feeds has speeded up growth of fish. Development of vaccines has decreased the use of antibiotics and increased survival together with better medicines. Radical changes in the seafood value chain have also come about alongside the growing demands on consumers. The push of supply of available fish from producers is turned into the pull of demand for the right kind of fish products from supermarkets. 
The presenters took the example of chicken. Annual consumption of chicken has increased from $4 \mathrm{~kg}$ to $16 \mathrm{~kg}$ per capita, which has meant that the product range has increased in ten years in Norway. Salmon still has fewer product launches than chicken, although that has increased too. For example, in nine selected European countries, there were 1,367 salmon and 2,724 chicken product launches during the last two years.

How have Norwegian salmon companies succeeded in the global markets? Lerøy is the world's second largest producer of salmon, with an annual turnover of about NOK 9,000 million. It delivers seafood to more than sixty countries worldwide from whole salmon to a range of value added products. It has taken a step-by-step approach to the market: production, logistics and distribution, product development and market innovations and marketing and branding. It has removed its business idea from trader to interactive food supplier and from low to high cost-value production. In innovations it has shifted from technology and process driven innovation to market-driven innovation.

It is clear that innovations are necessary for the future development of the aquaculture industry. Efficient and effective production is no longer enough to ensure competitive advantage; an understanding of markets is also needed.

The presentation can be downloaded from: http://www.rktl.fi/www/uploads/pdf/Aquaculture\%20Forum/theme_2_1_profitability_bergersen _iversen_final.pdf.

\subsubsection{New opportunities in Nordic aquaculture}

Jacob Bregnballe, Sales Director of Land-Based Aquaculture, AKVA Group, Denmark

Jacob Bregnballe presented AKVA Group, which is the global leader in aquaculture technology and management supplies. He reminded us that salmon farming comprises only 2.6 per cent of all aquaculture production in the world. AKVA Group is constantly developing new technologies for new farming species, such as recirculation farming of yellowtail kingfish in Saudi Arabia, shrimp in Thailand and bluefin tuna in land-based cage 
farming in Australia. The firm has also developed farming technologies for cobia, pangasius, sea cucumber and salmon.

Bregnballe sees the Nordic sea area as a natural resource for aquaculture: the Gulf Stream on the Norwegian shoreline for salmon farming, the Baltic Sea area for cage and mussel farming, freshwater for trout farming and salmon smolt farming in Norway. His opinion was that halibut, turbot, cod, arctic char, whitefish, pikeperch, perch, sturgeon and rainbow trout are all potential species for farming in the future. He gave an example of cod farming in Bornholm, deep in the Baltic Sea, where the most costeffective farming system is to release the first feeding fry in the sea. Running costs of the production of 474 million fry is EUR 300,000 and the expected return from fishing is EUR 2 million.

Jacob Bregnballe was sceptical about the future of small-scale household and aqua-pond farming. The future of micro and macro algae farming is still open to question. Recreational fishing and tourism, offshore farming in the Nordic sea area and sea ranching the Baltic Sea may be profitable in the future. He believes in the future of Norwegian salmon, rainbow trout farming in the Baltic Sea and organic farming. He sees aquaculture developing into closed systems like indoor "warm water" and recirculation farming and combined land-based cage farming. New idealistic ideas always have a chance of success if they are profitable. The key factors in aquaculture development are marketing, competitiveness and efficiency.

The presentation can be downloaded from: http://www.rktl.fi/ www-/uploads/pdf/Aquaculture\%20Forum/theme_2_2_profitability_ bregnballe.pdf.

\subsubsection{Profitability of rainbow trout production in Northern Europe}

Johan Åberg, President, Finnish Fish Farmers Association, Finland

Johan Åberg made a brief survey of Finnish rainbow trout production. In 1980 production stood at about 5 million $\mathrm{kg}$, with a value of around EUR 9 million, and it was mainly carried out inland. Production increased strongly up to 1991, with a shift to farming in the sea. Since then, production has 
decreased and was about 12 million $\mathrm{kg}$, with a value of about EUR 44 million in 2010.

The profitability of rainbow trout production is strongly connected to the prices of fish meal and oil which have increased during 2000s. As fish price varies, the profitability of production can be followed using the salmon price vs. food commodity index. Typical of this index are sharp and rapid changes between -10 per cent and +10 per cent with a maximum altitude from -20 per cent to +20 per cent during the 2000 s. A negative index means unprofitable production.

Another important factor in the profitability of rainbow trout farming is fish health. Mortality, treatment of fish and restrictions on selling after medicine use all decrease profitability. Antibiotic use has been low for ten years now but new diseases are a constant threat to the farming industry.

Johan Åberg considered that the key question for the future of rainbow trout farming is an environmental policy that allows for a response to the growing demand of aquaculture production as a global food producer. It is in the common interest of producers and the market that the supply and demand of fish is stable, and spot marketing will be transformed into longterm partnerships. Cooperation with the producer organisation and vertical integration in the production chain bring sustainability to the business. Rainbow trout farming should also improve productivity and cost efficiency. Fish health and welfare are also of great importance for the future of trout farming. Research and development that supports industry development are also key questions.

The presentation can be downloaded from: http://www.rktl.fi/www/uploads/pdf/Aquaculture\%20Forum/theme_2_3_profitability_aberg.pdf.

\subsubsection{The Norwegian miracle and future perspectives}

Trond Davidsen, Director, Norwegian Seafood Federation, Norway

Trond Davidsen presented the work of the Norwegian Seafood Federation. This organisation represents about 9,000 employers and 500 member companies in the seafood, fish meal, fish oil, fish feed, marine ingredients and aquaculture sectors. It promotes the interests of its members in legislation 
and industrials policy and export and internationalisation maters. It advises member companies on a wide range of issues including fish health, the environment, food safety, trade regulation and employee legal issues.

After forty years of commercial fish farming, production has passed one million tonnes in Norway. The main species in production is salmon, at 980,000 tonnes. Trout production accounted for 55,000 tonnes and cod 15,000 tonnes in 2011. In the export of the Norwegian seafood, the share of aquaculture product was 62 per cent (NOK 33.4 billion) and fisheries 38 per cent (NOK 20.4 billion) in 2010. Exports have increased for the last seven years. Norwegian seafood is a global product which produces 35 million meals every year for over one million consumers.

How has Norway achieved one million tonnes of production? The main reasons are the favourable natural conditions, the continuous development of business activities, a governmental framework promoting aquaculture, marketing activities, and cooperation and exchange of knowledge between government, research and the industry.

Some of the major challenges over the forty years of commercial aquaculture have been markets, cyclical prices, price dumping complaints, import restrictions and fish diseases. The situation in fish health has improved since 1990, and the number of outbreaks of diseases had decreased by 25 per cent. New fish diseases are always a potential problem for salmon farming.

The two major challenges for the future of salmon farming are sea lice and escapees from cages. Sea lice are the most common parasite on salmon, and their numbers have increased with their hosts. It constitutes a challenge both for the aquaculture industry and wild salmon populations. Norway has an action plan for the sea lice problem through improving the collaboration, skills and practices of operators. New treatments are also developed like the use of cleaner fish (wrasse) that eat the parasites in cages. Research is looking at potential new ways of increasing salmon tolerance of sea lice like vaccines, the breeding of salmon and development of feed.

Since 2006, the number of escapees has decreased despite the increase in production volume. Nowadays it amounts to about 200,000 individuals per year. Actions to reduce escapees include technical standards for farming equipment, education of farmers, a governmental commission focused 
on the problem and research looking for reasons for the problem and management and technology options to solve the problem.

Like many other speakers, Trond Davidsen stressed the importance of aquaculture for animal protein produce in the future and its environmental efficiency. Despite that he saw that global campaigns against the salmon industry are one challenge for future development. The other challenges are cyclic prices, ongoing economic turmoil and political goodwill to permit access to sea areas, sufficiency of raw materials for fish feed and overproduction. He sees that the future developmental needs of the Norwegian aquaculture industry will make it more professional, through effective handling of parasites and diseases, improved technology and more suitable sea sites for farming. It is also important that salmon farming is more politically acceptable. He saw that handling of sea lice and escapee problems as crucial in the gaining of this acceptance.

The presentation can be downloaded from: http://www.rktl.fi/www/uploads/pdf/Aquaculture\%20Forum/theme_2_4_profitability_davidsen. pdf. 



\section{Acceptability - Success in competition for the souls of customers - quality, organic production, eco-labelling}

\subsection{General summary of the presentations and discussions}

This session concentrated on eco-labelling and organic production. Environmental certification is a business which is carried out because it is profitable for certifiers and for trade, but at the same time it uses retailer buying power to reduce the environmental impacts of the production of commodities. Behind it lies goodwill, but current practice may not serve the ideology and consumers in the best possible way. As different organisations can quite freely create and allow the use of their own labels, there may be several labels on the same product which can be confusing to consumers. Consumers may not know what criteria are behind the label but still they want to see them on the packages in order to provide them with peace of mind. In fact, it is mainly the retailers who use the labels to reinforce their credibility and show their commitment to protecting the environment. Traders can choose which certification system they favour in their product selections. There are numerous types of certification of commodities, for example environmental, social, animal welfare and food safety. Ultimately it is consumers who bear the cost of labelling.

WWF is a pioneer in certifying production. WWF uses the system to create pressure to develop production more sustainability. WWF uses multi-stakeholder commodity roundtables to develop certification standards. One question might be: should international governmentally-steered organisations like the FAO and the OECD be the ones who develop the 
certification systems and permit licences to organisations to carry out the certification and permit labels? At the present time, the FAO has a number of guidelines governing how certification schemes should be developed particularly for fisheries and aquaculture.

Organic production differs from other sustainable eco-labelling products because there are laws (EU and national) that regulate the production. However, there are differences in opinions regarding the advantages of the quality and fish welfare of organic production. The tight regulation narrows the possibilities of developing production and it may decrease the profitability of the production by increasing costs.

\subsection{Summaries of the presentations}

\subsubsection{Certification and eco-labelling: fact, fiction and future}

Carl-Christian Schmidt, Head of Fisheries Policies Division, Directorate for Trade and Agriculture. OECD

Carl-Christian Schmidt presented the history of eco-labelling in fisheries. It all began as late as the 1990s through collaboration between Unilever and WWF. At that time Unilever was working on three sustainability action strands for fish, water and tea. Unilever also made huge investments in fish food production. At the same time, WWF was concerned over fish stocks and started a fisheries sustainability campaign in the UK. WWF also has the need to provide income from members and funders. In common they wanted to harness market forces and mechanisms to achieve their shared objective of sustainable fisheries.

Certification and eco-labelling are carried out because it is a profitable business for promoters of labels, and for certifiers and scientists on certification teams. For logo users there is little evidence of a price premium although this could be a reflection of the market competition. For retailers, however, certification increases possibilities for product diversification and for consumers it gives peace of mind. 
Under current practices organisations can promote their own labels and this has led to a high number and a variety of labels. There are several labels for the same issue but with some notable differences that are not necessarily communicated to the consumer. This may relate to the certification standard or the way the certification is taking place. These differences create "eco-label noise" which confuse consumers that expect clarity and simple messages around the sustainability of the products of all certification systems. The situation has also shifted influence from consumers to retailers as the retailers can choose (so-called "choice editing" which label-type they will wish to place on the products they sell.

There is competition on several fronts in the label business. Promoters of labels can compete on "trust" in their label, the price of certification and the costs of using the label. Concurrently, standard owners can promote their individual labels.

Currently, consumers are confused or at best are not informed about all the details behind labelling. It is important that governments and international organisations work towards an agreed and shared definition of sustainability. It is also important to "certify the certifier" to make the systems more credible in the eyes of the consumer.

One interesting model highlighted is the Green Claims Code of the Department for Environment, Food and Rural Affairs (DEFRA) in the United Kingdom. The Code has many positive aspects and provisions: it considers the full environmental impact of product, it checks that claims are relevant, it takes additional benefits of claim into account, comparisons are fair and relevant, it is truthful and accurate, it has clear scope and boundaries, the language is plain, evidence is clear and robust and information to substantiate claims are readily available.

Labelling will continue to develop in the future if there is money to be made. New certification areas will come, such as carbon footprint, food miles, water foot print, life cycle assessment, animal welfare, etc. The big question is: do we really need labels from the consumer perspective?

The presentation can be downloaded from: http://www.rktl.fi/www/uploads/pdf/Aquaculture\%20Forum/theme_3_1_acceptability_schmidt_ $0 . p d f$. 


\subsubsection{Challenges of organic aquaculture - the Danish case}

Alfred Jokumsen, Senior Advisory Scientist, Technical University of Denmark, Denmark

Alfred Jokumsen presented the organic aquaculture production in Denmark, which currently amounted to about 300 tonnes of rainbow trout in freshwater and 50 tonnes in seawater, and 10 tonnes of mussels. Globally there were about 240 organic aquaculture producers in 29 different countries, around half of whom are in Europe.

Organic aquaculture has been regulated by national legislations (in Denmark it came into force in 2004) but these were replaced by the common European Commission regulation (EC No. 710/2009) on organic aquaculture animal and seaweed production, which entered into force on 1 July 2010. However, there will be a transition period of 4-5 years to adapt to the common EU regulation. Regulations of the legislation include the origin of production material which allows the use of non-organic juveniles in production up to a maximum of 80 per cent by the end of 2011, 50 per cent by the end of 2013 and none at all by the end of 2015 . The organic life cycle must be complete at the beginning of 2016. Stocking density of trout should be $\leq 25 \mathrm{~kg} / \mathrm{m}^{3}$. Two medication and parasite treatments per year are allowed if the life cycle is over one year and 1.5 year, respectively. In feed, raw material derived from organic aquaculture, sustainable fishery and plants (max 60 per cent) from organic production should be used. However, there is a transition period for adapting the feed regulations until 31 December 2014. Only mechanical aerators are allowed and renewable energy sources are preferred. The use of pure oxygen is only permitted in critical situations. Closed recirculation systems are not permitted, with the exception of hatcheries and fry rearing.

Basically, organic production aims to replicate the cycle of nature. In extensive production, such as omnivorous fish, seaweed, molluscs and polyculture farming, where the input of feed is minor or non-existent, it is in line with organic principles. Organic farming of carnivorous fish, i.e. salmon, is more complicated because of the demand on raw material for feeds. 
Strict regulation of organic production is a challenge. Limited treatment possibilities of fish create pressure to develop robust fish and brood stocks and health inspection of fish. Small production volumes, relatively heavy costs of environmental supervision, control of production and certification, and transportation distances (carbon foot-print) are market barriers. However, Europe is a big potential marketing area for organic aquaculture products. It may also lead to the development of rural areas' employment and social structures.

The presentation can be downloaded from: http://www.rktl.fi/www/uploads/pdf/Aquaculture\%20Forum/theme_3_2_acceptability_jokumse n.pdf

\subsubsection{Consumers preferences and industry adaptations}

Timo Vetriö, Managing Director, Chipsters Food Ab, Finland

Timo Vetriö presented Chipsters Food Ab, which is a Finnish seafood company servicing food services and retailers. When consumers are asked how they want their fish, the answer is "like meat" but in practice more and more processed products are being purchased, as with chicken products. One exception is sushi, the consumption of which has increased, especially among youngsters. Consumer demand in the industry has increased the variety of processed products some years now. That is why organically farmed fish and eco-labels have taken to product selection.

Customers are well aware of the good qualities of fish. It is a light and healthy food with high levels of omega-3 fatty acids and vitamin D. Some discussion has arisen among consumers concerning the fact that about half of the oils in salmon are nowadays vegetable oils coming for feed. In terms of price, fish is a competitive source of protein when compared with other animal products.

The presentation can be downloaded from: http://www.rktl.fi/www/uploads/pdf/Aquaculture\%20Forum/theme_3_3_acceptability_vetrio.pdf. 


\subsubsection{WWF working towards a sustainable future for aquaculture}

Dr Piers Reid Hart, WWF

Piers Hart explained WWF's relationship with aquaculture. WWF has a number of goals which are related to aquaculture and it recognises the positive aspects as well as the negative. WWF also recognise that the proportion of farmed seafood in animal production will increase in the future. It has estimated that production will increase from 13 per cent to around 19 per cent and the share of fisheries will decrease from 16 per cent to around 10 per cent from 2006 to 2050 as the total volume of animal production increases and fisheries output remains constant. The positive aspects of aquaculture are a low carbon and freshwater footprint and high efficiency of feed conversion compared with other animal production methods. Other positives are the use of minimal or no arable land, and the health benefits of seafood for humans. Aquaculture of certain species may reduce fishing pressure on natural stocks.

On the other hand, aquaculture has negative impacts which WWF wants to improve. Such things are the levels of escapees that can reduce the biodiversity of natural populations and the spread of disease and parasites such as sea lice, to wild populations. It can also have negative impacts on water quality and benthos. For some species, the feed used may have negative impacts on biodiversity and wild fish stocks. In some countries there may be negative social and labour impacts.

WWF has many tools with which they try to reduce the negative impacts of aquaculture. WWF has partnerships with retailers relating to the sustainable sourcing of products and consumer labelling. They produce a seafood guide in some countries, which is a traffic light system relating to the sustainability of different fish species, and fisheries and aquaculture improvement projects. WWF uses multi-stakeholder-developed certification standards to reduce the impacts of commodities. The seafood certification schemes which WWF supports are the Marine Stewardship Council (MSC) and the Aquaculture Stewardship Council (ASC).

In aquaculture, WWF has facilitated eight roundtables concerning twelve species. A variety of different stakeholder groups, farmers, conser- 
vationists, academics, governmental officials are represented on the roundtables, with the aim of developing standards for responsible aquaculture. The standards are decided upon by multi-stakeholder steering groups (8-9 people) with input from the broader community and are completely transparent to the public. The standards will be managed by the ASC when they are completed in 2012.

The ASC is an independent global organisation that will employ an independent Accreditation Body and independent Certification Bodies to undertake the audits. ASC took possession of four aquaculture dialogue standards in May 2011 covering tilapia, pangasius, oysters, mussels, clams, scallops and abalone. Currently it is defining the accreditation criteria for independent global certification bodies and has set up of a technical advisory group to define auditor guidance and standard alignment. It is also aligning with MSC on the chain of custody certification and accreditation.

The presentation can be downloaded from: http://www.rktl.fi/www/uploads/pdf/Aquaculture\%20Forum/theme_3_4_acceptability_hart.pdf. 



\section{Attractivity - Success in competing for capital and labour}

\subsection{General summary of the presentations and discussions}

This session considered how to create circumstances in aquaculture so that it will attract companies, capital and labour in the future. First, the EU and national governments have to enact policy and regulations that enables the long-term development of aquaculture. The $\mathrm{EU}$ is renewing its Common Fisheries Policy and there is goodwill to promote aquaculture development and marketing. EU regulations do not diminish the national role of government to promote aquaculture. At the national-level, ministries at the frontline between environmental and industrial policy, should remove conflicts and shift to a win-win situation. Goals and strategies should be clearly defined so that all parties can agree them and work by agreement. The work of the authorities that grants permits should provide support for unique and simple instructions and decrease the administrative burdens. Farmers hope that regulation would not increase the cost of production.

New innovative industry solutions may increase the attractiveness of aquaculture. The new farming technologies and new tasks in seafood production diversify the job. The aquaculture industry is no longer about farming fish; it is now concerned more and more with the whole value chain. Using by-products like fish waste as a raw material for new commodities like bio-fuels creates new jobs.

The usefulness of fish waste as a raw material for bio-fuels depends on its fat content. 1,000 kg of fish waste with a fat content of 45 per cent produces $300 \mathrm{~kg}$ of biodiesel. Fish waste with a fat content below 10 per cent 
cannot be used as a raw material for bio-fuels. Fish waste is, however, expensive and the total amount is small compared to waste from slaughterhouses.

\subsection{Summaries of the presentations}

\subsubsection{Aquaculture in the new Common Fisheries Policy reform package}

Hannu Lovén, Desk Officer, European Commission, DG Maritime Affairs and Fisheries, Finland

Hannu Lovén presented on the issue of aquaculture production in EU27 countries, which has remained behind the levels of global development and that seen in Norway. Around 650,000 tonnes of molluscs and crustaceans are produced along with around 300,000 tonnes of both marine and freshwater fish. In the Baltic Sea region, the biggest producers are Germany, Poland and Denmark, with less than 40,000 tonnes per year per country. Aquaculture is not a marginal sector in the EU but it is far away from reaching its potential. Lovén also reminded us that in Europe, aquaculture encompasses a wide range of sectors, from cultural heritage to innovative and high tech businesses.

The new Common Fisheries Policy (CFP) is designed to give aquaculture a new impetus and remove the bottlenecks for development. In the reform package a substantial contribution to the development of jobs and local areas both in marine and fresh water aquaculture will be provided for. The reform pays attention, among other things, to sustainability, smart growth and profitability of aquaculture, animal health and environmental issues. A substantial contribution will also be given to the market for aquatic food. In the CFP reform package a new impetus to the EU Aquaculture Strategy 2009 will be given, which is concretised now in proposals for a reformed CFP. The reform will take into account the different situations between countries. The reform consists of three basic pillars: basic regulation, market regulations and the financial instrument. 
Aquaculture is a full pillar of the reformed CFP. Union strategic guidelines on common priorities and targets for the development of aquaculture activities are to be established by 2013. On this basis, member states shall establish a multiannual national strategic plan for the development of aquaculture activities in their territories by 2014. Exchange of information and best practices through an open method of coordination of the national measures will be contained in multiannual strategic plans.

The Advisory Council on aquaculture will be established. It will gather up information on problems, recommendations and suggestions on matters relating to aquaculture. The Advisory Council represents the operators and other interest groups in general assemblies and executive committees and it may apply for EU financial assistance. The Commission adopts delegated acts concerning the composition and the functioning of Advisory Councils.

One goal in the reform of Market Regulation is for the producer organisations to have a stronger role in the management and planning of production and placement on to the market. It will also tailor the specificities in fishery and aquaculture. The structure of producer organisations is also desirable, in order to reinforce to the inter-branch organisation with better coordination along the value chain and develop transnational organisations. Market intelligence in aquaculture is required to improve economic knowledge of EU markets, survey prices and market trends for organisations to use.

The coordination of the financial instrument will be renewed and it will bring together the present funding streams. The reform is looking for synergy and the development of co-working and diminished levels of bureaucracy.

The presentation can be downloaded from: http://www.rktl.fi/www/uploads/pdf/Aquaculture\%20Forum/theme_4_1_attractivity_loven.pdf. 


\subsubsection{Moving towards win-win governance of aquaculture}

Orian Bondestam, Ministerial Adviser, Ministry of Agriculture and Forestry, Finland

Orian Bondestam presented on the shared concern about the aquaculture production decrease in Finland. In the 1980s the increase in the sea cage farming of rainbow trout was uncontrolled, leading to local water quality problems in Finland. The consequence was that the environmental officials' main goal has been a systematic reduction of nutrient load and production. The contradiction between environmental and aquaculture industry policy has continued. Short-term permits with strict conditions have not supported the industry in Finland. Rainbow trout production has had to compete with large-scale salmon production in Norway, pushing down prices in Finland too.

In seafood, Finland is no longer self-sufficient. The share of imported fish in Finnish consumption has increased strongly. In 1999 it was even but now the share of domestic fish is only 30 per cent.

One of the roles of government is to create favourable circumstances for aquaculture. In the future development of aquaculture in Finland, it is crucial to find a win-win path between the authorities and stakeholders to ensure continued dialogue and coherence between environmental and aquaculture policies. Goals should be defined so that all parties can agree on them and so they can develop new and innovative solutions to achieve them. A good start would be a consensus to ensure the good status of marine and inland waters and aquaculture growth to ensure domestic fish supply.

On the route to a better aquaculture future, the Finnish government adopted a national aquaculture strategy in 2009. In the strategy, the sustainable growth of aquaculture is an objective, making use of new innovations, species and technologies. Part of the strategy is developing international cooperation under the EU strategy for the Baltic Sea region and its BESTAQ and AQUABEST projects. The aim is also to define incentives for the use of new management tools like the recirculation of nutrients in the Baltic Sea through the use of Baltic fish as a raw material in feed. Spatial planning is also taken into use for the preparation of plans to locate aqua- 
culture in favourable areas. Instructions for the authorities that grant permits are also developed and administrative burdens are reduced.

The presentation can be downloaded from: http://www.rktl.fi/ www-/uploads/pdf/Aquaculture\%20Forum/theme_4_2_attractivity_ bondestam.pdf.

\subsubsection{Creating sustainable aquaculture business}

Esko Pettay, Director of Development, Meriaura Group, Finland

Esko Pettay presented Meriaura Group, which specialises in energy logistics. The group employs 350 people in Finland. Its vision is to be at the frontline in developing sustainable logistics and energy solutions. Meriaura Group consists of three firms. Sybimar Ltd specialises in the research and development of renewable energy technology and manufacturing equipment for the food industry. It also produces bio-fuels, like biooil, diesel and gas from food industry waste from slaughter houses, fish farms and chicken yards, as well as utilising low value catch. At present, the firm is building a new renewable energy and food producing complex in Uusikaupunki on the west coast of Finland. The idea is to raise fish and vegetables and circulate nutrients and water between fish farm and greenhouse. Waste biomass goes to bio-fuel and bio-gas production. The power plant carbon dioxide is circulated to the greenhouse.

Meriaura specialises in project logistics and offshore wind farms. The firm has two bio-oil cargo vessels which specialise in marine wind farms building and maintenance.

Biota Tech Ltd is a specialist in environmental technology, energy efficiency and bio energy, environmental and natural resources management and climate change.

The presentation can be downloaded from: http://www.rktl.fi/www/uploads/pdf/Aquaculture\%20Forum/theme_4_4_attractivity_pettay.pdf. 



\section{Closing session}

The conference organisers intended to end the conference with a commonly agreed declaration. This goal was included in the official programme of the conference. At the beginning of the conference the organisers provided a draft declaration to the participants and at the end of the first day made the conference aware of their ambition of drafting a declaration. As the final point of the conference programme, Orian Bondestam of the Finnish Ministry of Agriculture and Forestry, which organised the conference, presented the draft declaration. This was followed by a paragraph-by-paragraph discussion, resulting in commonly agreed amendments to the draft. At the end of the discussion, the conference was able to unanimously agree on a "Helsinki Declaration on Competitive and Sustainable Aquaculture in the Baltic Region," as presented below.

\subsection{Helsinki Declaration on Competitive and Sustainable Aquaculture in the Baltic Region}

Seafood is a very important part of a well-balanced and healthy diet, providing nutritious protein, vitamins, minerals and trace elements as well as valuable fatty acids. Consumers are increasingly aware of the health benefits of a fish and seafood-rich diet to counter obesity and lifestyle diseases.

The consumption of seafood in Europe greatly exceeds supply levels from European fisheries and aquaculture, resulting in a dependency on imports.

At the global level the supply of wild fish has stagnated and is not expected to expand in the future. Simultaneously, global aquaculture has grown and now provides half of the world's supply of fish for food.

Growth of European Union aquaculture has stagnated and lags behind global development levels as well as in countries neighbouring the European Union. With rising concerns on issues such as climate change, food 
security, dietary impacts on health, food production footprints and efficiency as well as the need to develop rural and coastal economies in Europe, the role and future of European aquaculture needs to be examined.

The Aquaculture Conference held in Helsinki on $4^{\text {th }}-5^{\text {th }}$ October 2011 as part of the Finnish Presidency program of the Nordic Council of Ministers has explored possible dimensions and tools for developing competitive and sustainable aquaculture in Northern Europe. The conclusions of the Conference are summarised as follows:

1. Aquaculture in the Baltic Region has the potential to play a key role in increasing the supply of high quality, healthy seafood to consumers

2. A substantial increase of sustainable aquaculture in waters of the Baltic Region, both at sea and inland, needs to be targeted so as to fulfil this potential

The achievement of these goals imposes the need for a significant rise in competitiveness, accompanied by encouraging and enabling actions for development that the Conference summarised as:

- Providing clear and comprehensive development strategies for the sustainable development of aquaculture in the Baltic Region

- Developing and applying policies that enable environmentally-efficient and market-oriented production growth in areas favourable for aquaculture - be this marine, freshwater or land based

- Allowing for production permits that encourage long-term investment, reduce administrative burdens and support sustainable development and profitability and thus contributing to green growth

- Establishing dialogue and solid partnerships between environmental and aquaculture administrations, as well as with stakeholders and research, that aim to apply a system of aquaculture governance that benefits all members of society

- Mobilising the use of new raw materials and the recirculation of valuable nutrients within the Baltic Region as contributions to the bioeconomy e.g. for the manufacture of high-performance fish feeds

- Encouraging skills and career development within the production and service sectors that support aquaculture 
- Creating the framework conditions for the successful use of innovation in aquaculture

- Welcoming the proposal for an Advisory Council on Aquaculture as proposed by the European Commission 



\section{Sammandrag}

\subsection{Hållbar utveckling inom akvakultur}

Tillståndet för Östersjöområdets akvakultur och framtida utvecklingsbehov dryftades ur flera olika perspektiv på den internationella konferens om akvakultur som Vilt- och fiskeriforskningsinstitutet och jord- och skogsbruksministeriet arrangerade på Ständerhuset i Helsingfors 4-5.10.2012. Inalles 125 representanter för EU, ministerier, forskningsinstitut, producenter, foderindustrin och organisationer från 13 länder i Europa deltog. Konferensen var en del av Finlands ordförandeskapsår i Nordiska ministerrådet, som även finansierade evenemanget. Gemensamt för de europeiska länderna konstaterades vara en minskande akvakulturproduktion och en ökande import samt faktorer som begränsar akvakulturen, till exempel bristen på odlingsplatser samt kortvariga och stränga miljötillstånd. Ett undantag utgör Norge, som utöver de asiatiska länderna har lyckats utöka sin produktion kraftigt. Även om Norges naturförhållanden inte kan kopieras, kan man ta exempel därifrån liksom från Danmark på samarbete mellan olika aktörer och måluppställningar.

En grundförutsättning för akvakulturutvecklingen är en miljömässigt hållbar produktion. Genom lokaliseringsstyrning kan fiskodlingens belastning på vattendragen minskas och genom recirkulation av näringsämnen kan vattendragens tillstånd eventuellt till och med förbättras. I slutna system där näringsämnen och vatten recirkuleras kan produktionen även föras närmare konsumenterna. Danmarks Tekniske Universitet DTU arrangerade som en fortsättning på konferensen ett seminarium om recirkulation i anslutning till akvakultur 6.10.2012. Inom detta område öppnar den tekniska utvecklingen kontinuerligt nya möjligheter.

Konsumentens köpbeslut påverkas främst av produktens pris. Detta sätter press på att produktionen är ekonomiskt lönsam. Man måste även kunna reagera på konsumenternas behov genom att öka förädlingsgraden och produkturvalet. Ett exempel är den ökande efterfrågan på sushi. På 
konferensen konstaterades också att dagens brokiga utbud av miljömärken för fiskprodukter till och med förvirrar konsumenterna.

För att trygga tillgången på inhemsk odlad fisk även i framtiden måste branschen kunna locka till sig företagare, placerare och medarbetare. I utvecklandet av akvakulturen är lokaliseringsstyrning, ny teknik och flexibel tillståndspolitik till fördel för såväl myndigheterna, miljön som producenterna. Dessa och även andra mål antecknades i den kommuniké om akvakultur som godkändes på konferensen (Helsinki Aquaculture Declaration) för utveckling av en konkurrenskraftig och hållbar akvakultur inom Östersjöområdet. Kommunikén och föredragen från konferensen kan läsas på http://www.rktl.fi/english/economics_and_society/aquaculture_forum/ 


\title{
7. Conference programme
}

Conference on Competitive and Sustainable Aquaculture, 4-5 October 2011.

Dimensions and Tools of Competitive and Sustainable Aquaculture in Northern Europe

Conference venue: House of Estates, Snellmaninkatu 9-11, Helsinki, Finland

\author{
Monday 3 October \\ 20:00-22:00 Get together and registration, House of Estates \\ Tuesday 4 October \\ 08:00-09:00 \\ Registration \\ 09:00-09:15 Opening and welcome by organisers from the Finnish Game and Fisheries Research \\ Institute and the Ministry of Agriculture and Forestry \\ 09:15-10:00 Opening keynote: Aquaculture in the global scale by \\ Brian Thomsen, Danish Aquaculture Organisation \\ 10:00-10:30 Coffee break \\ 10:30-11:00 Introduction keynote: State of aquaculture in Nordic countries by \\ Brian Thomsen, Danish Aquaculture Organisation
}

Tuesday 4 October

11:00-12:30

THEME 1: SUSTAINABILITY

Moderator Courtney Hough, Federation of European Aquaculture Producers (FEAP). Presentations one hour followed by panel discussions for $30 \mathrm{~min}$

- Bottlenecks in the Baltic Sea region aquaculture and their potential solutions. Jouni Vielma, Finnish Game and Fisheries Research Institute

- $\quad$ Feed as the key to sustainable aquaculture. Anders Kiessling, Swedish University of Agricultural Sciences

- Marine spatial planning and aquaculture - a Norwegian perspective. Martin Bryde, Ministry of Fisheries and Coastal Affairs

- Potential and limitations of aquaculture in freshwater systems. Jens Andersson, Jämtland Region 
Tuesday 4 October

13:30--15:00

THEME 2: PROFITABILITY

Moderator Courtney Hough, Federation of European Aquaculture Producers (FEAP)

Presentations one hour followed by panel discussions for $30 \mathrm{~min}$

- Value-adding in the production chain for fish products. Renate Enemark Bergersen (Econ Pöyry) and Audun Iversen (Nofima)

- New opportunities in Nordic Aquaculture. Jacob Bregnballe, AKVA Group

- Profitability of rainbow trout production in Northern Europe. Johan Åberg, Finnish Fish Farmers Organisation

- Norwegian miracle and future perspective. Trond Davidsen, Norwegian Seafood Federation (FHL)

15:00-15:30 Coffee break

Tuesday 4 October

15:30-17:00

THEME 3: ACCEPTABILITY

Moderator Courtney Hough, Federation of European Aquaculture Producers (FEAP)

Presentations one hour followed by panel discussions for $30 \mathrm{~min}$

- Certification and Eco-labelling: Fact, Fiction and Future.

Carl-Christian Schmidt, OECD, Directorate for Trade and Agriculture

- Challenges of Organic Aquaculture - Danish Case.

Alfred Jokumsen, DTU Aqua, Technical University of Denmark

- Consumers preferences and industry adaptations.

Timo Vetriö, Chipsters Food Ab

- WWF working towards a sustainable future for aquaculture.

Piers Reid Hart, WWF

17:00 Summing up day one and presentation of the Helsinki Aquaculture Declaration.

Moderator and organisers

Tuesday 4 October

20:00-22:30 Conference dinner, Restaurant Uunisaari

\section{Wednesday 5 October}

09:00-10:30 THEME 4: ATTRACTIVITY

Moderator Courtney Hough, Federation of European Aquaculture Producers (FEAP)

Presentations one hour followed by panel discussions for $30 \mathrm{~min}$

- Aquaculture in the new Common Fisheries Policy and European Fisheries Fund. Hannu Lovén, European Commission, DG Maritime Affairs and Fisheries (DG MARE)

- Moving towards win-win governance.

Orian Bondestam, Ministry of Agriculture and Forestry

- Creating attractivity in sustainable aqua-culture business. Esko Pettay, Meriaura Group

10:30-11:00

Coffee break

$11: 00-12: 00$

Closing session

- Concluding remarks and Helsinki Aquaculture Declaration

- Courtney Hough (FEAP) and Orian Bondestam (Ministry of Agriculture and Forestry)

$12: 00-$

Press conference, organisers

12:00-14:00

Lunch

Aquaculture Forum continues with RAS Workshop, Programme in www.NordicRAS.net 
Nordic Council of Ministers

Ved Stranden 18

DK-1061 Copenhagen K

www.norden.org

\section{Conference on Competitive and} Sustainable Aquaculture

The conference was organised by the Finnish Game and Fisheries Research Institute and the Ministry of Agriculture and Forestry. A separate Workshop on Recirculating Aquaculture Systems, also financed by the NCM and organised by Technical University of Denmark (DTU), was linked to the conference (www. NordicRAS.net). Together, these two consecutive events formed the Aquaculture Forum.

The conference brought together 125 participants from thirteen different European countries. There was broad representation from the aquaculture sector in Europe: central and local administrations, research institutes, universities, industry and a range of other organisations. 